\title{
IDENTIFICATION OF THREAT AND PRESSURE FACTORS ON PROTECTED AREAS USING RAPPAM METHODOLOGY (CASE STUDY: KHUZESTAN PROVINCE, IRAN)
}

\author{
MOHSENI, F. ${ }^{1}-$ SABZGHABAEI, G. R. ${ }^{1,{ }^{*}}-$ DASHTI, S. ${ }^{2}$ \\ ${ }^{1}$ Department of Environment, College of Natural Resources and Environment, \\ Behbahan Khatam Alanbia University of Technology, Behbahan, Iran \\ ${ }^{2}$ Department of Environment, Ahvaz Branch, Islamic Azad University, Ahvaz, Iran \\ *Corresponding author \\ e-mail: grsabz1@gmail.com,Sabzghabaei@bkatu.ac.ir
}

(Received $1^{\text {st }}$ Aug 2017; accepted $18^{\text {th }}$ Dec 2017)

\begin{abstract}
Given the significance of conserving and improving lands management with a high conservation value, chosen for conserving and recovering plant and animal habitats as protected areas on a large scale, this study was conducted with the aim of identifying threat and pressure factors of protected areas in Khuzestan Province, Iran. In this study at 2015, using Delphi method, the threat and pressure factors of protected areas in Khuzestan Province were identified. Next, using RAPPAM methodology presented by WWF organization for managerial effectiveness of protected areas, the greatest threat and pressure factors of regions were investigated by individual regions and collectively for all of the regions. The results of this study suggest that five major factors of collective threat and pressure across all protected areas in Khuzestan Province in Iran are overgrazing (405.07), dam building (374.25), shortage of workforce and equipment (338.22), conversion of land use (283.23), cutting of trees (243.72). In contrast, the lowest threat and pressure factor was the effects caused by immigration of nomads (43.88). Among the protected areas studied in Khuzestan Province, the greatest collective threat and pressure factor is related to Dez protected area (674.41), while the lowest threat and pressure factor is related to Koraii protected area (342.51). Thereafter, attempts have been made to present some suggestions to solve or mitigate the effects of these factors given the pressure and threat factors present in the protected areas of Khuzestan Province. Among these solutions can one mention offering the license of grazing to local communities in the area in a periodical fashion, consideration of incentive measures for the area's staff in order to enhance motivation and aid in conservation of the area, holding training courses for the staff suited with the new needs of the area, recovery of the boundaries of the protected areas to prevent to transgression to the area and alteration of land use.
\end{abstract}

Keywords: overgrazing, biodiversity, dam building, deforestation, Delphi method

\section{Introduction}

Protected areas are regions of land or sea that are kept specifically for conserving and maintaining biodiversity, natural resources, and contract resources in order to be managed and conserved legally through common traditional methods (Giuliani, 2007; Rana et al., 2010). Today, these regions are vital instruments for preserving biodiversity in the face of the global crisis of extinction of species and losing universal natural capacity for supporting human habitat. Furthermore, these regions are crucial for guaranteeing a healthy society which provides diversity of life by preserving the species and habitats. They also help survival of living creatures, each of which is a product of millions of years of evolution on the earth (Secretariat of the Convention on Biological Diversity, 2008). Suitable management of protected areas requires full understanding of the existing conditions, accurate implementation and planning as well as regular 
supervision. Sometimes there is a need to develop some changes in the management of a protected area if required (Nolte et al., 2010).

In 2010, a report was published across Europe entitled evaluation of the effectiveness of management of protected areas. In this study, RAPPAM [Rapid Assessment and Prioritization of Protected Area Management] method is known as one of the international and valid methods for evaluating the effectiveness of management of protected areas (Hockings et al., 2010). RAPPAM method, WWF [Wildlife World Federation] which is one of the persistent attempts for developing a special evaluation instrument congruent with the framework of WCPA [World Commission on Protected Areas], is one of the most common methods of evaluation of effectiveness of management of protected areas in the world. Through this method, over 1600 protected areas have been examined in 49 countries (Leverington et al., 2010).

In studies conducted on the pressures and threats of protected areas using RAPPAM methodology in different countries, various factors have been identified as threat and pressure factors. According to RAPPAM methodology, pressure refers to activities and processes that incur harmful damages to the integration of the protected area such that it results in decreased biodiversity or biocapacity or damage to natural resources. This pressure might be caused by legal or illegal activities either directly or indirectly. Threat refers to a potential pressure as a result of which destructive effects might take place in the protected area (WWF, 2003).

In a study conducted in Russia, hunting, tourism, and natural disasters were identified as the most extensive threat and pressure factors of protected areas, where these factors have been detected in over $90 \%$ of areas (Tyrlyshkin et al., 2003). In South Africa (2003), in all areas, the attack of foreign plants has been the most important pressure and threats factor of areas due to alteration of land-use in protected areas to agriculture and other usages (Goodman, 2003). In Butane (2003), the major threat and pressure factors in protected areas in the country are caused by illegal hunting, overgrazing, road construction, and construction in general (Tshering, 2003). In Georgia (2003), hunting and overgrazing are among the major factors of threat and pressure for the protected areas (Zazanashvili, 2003). In China (2003) and among the serious threat and pressure factors for areas are increased tourism, illegal hunting, and commercial use of forests (apart from timber cutting) ( $\mathrm{Li}, 2003$ ). In a study conducted in Cambodia (2004), it was found that $53 \%$ of threat factors of the country's protected areas is related to forest clearing (cutting of trees) and the most important pressure factors of the areas in the country are caused by illegal cutting of trees, illegal hunting, fishing, and extraction of nontimber forest products (Lacerda et al., 2004). In Mongolia (2005), illegal hunting in the wildlife claimed the highest score among the pressure and threat factors in the protected areas in this country (Batsukh and Belokurov, 2005). In Nepal (2006), overgrazing has the highest score of pressure and threats factor for protected areas in Nepal (Nepali, 2006). In Romania (2006), the considerable threat factors in areas are legal and illegal harvest of timber trees, altered land-use, and illegal hunting. The important pressure factors are altered land-use and entrance to the system and inappropriate management of wastewater as well as construction (Stanciu and Steindlegger, 2006). In a study carried out on the effect of urbanization in tropical Mangrove forests in Fortalza, Brazil (2008), hunting, fishing, entrance to areas, harvest of wood, collection of nontimber wood, activities in land adjacent to protected areas, and tourism have been identified as the most serious threats in protected areas of this region (Leverington et al., 2008). In Brazil (2010), the greatest threat and pressure 
factors introduced to the areas of this country are caused by the activities related to living creatures in the area (Simões et al., 2010). In a study performed for rapid evaluation of the pressure factors in protected areas along with the threat factors in national parks, the greatest threat factors of national parks were related to grazing, hunting, harvest of timber trees, and fishing. These threat and pressure factors are directly related to the vulnerability of the area (Nchor et al., 2012). In a study dealing with analysis of the threat and pressure factors in wetlands of South of Iran using RAPPAM method in Khuzestan Province (2014), it was found that extensive changes in land use into residential and agricultural uses, exhaustion and fracture of oil pipes and oil products in the wetland, legal and out of season hunting claimed the highest scores of pressure and threat factors, respectively (Sabzghabaei et al., 2014). In a study carried out on the evaluation of the effectiveness of management in Mangro protected areas in a 10-year period (2016), it was concluded that across all the years, factors including animals, harvest of plants, residential areas, firing, and the hazards caused by pollution have claimed considerable effects in Environmental Protection Agency (EPA), most of which would probably be irreversible. However, in 2006 and 2012, the managers of protected areas stated that progression of residential areas is considered a threat for preserving natural resources (de Almeida et al., 2016). Protected areas in Iran have been divided into four groups by Iran's environmental management (DOE), and these areas have grown considerably over the past 10 years in Iran. In total, Iran possesses 253 protected areas accounting for around 10.12\% of Iran's area (Mirkarimi, 2007). From among the 514 bird species existent in Iran (Mansoori, 2008), 285 species have been identified in Khuzestan Province (Nabavi et al., 2010). Similarly, from among 194 mammal species in Iran (Zyaii, 2008), 58 species have been identified in Khuzestan Province (Nabavi et al., 2010). The Iranian yellow deer species, on the verge of extinction, has been preserved artificially in natural and enclosed parks for many years, and Dez and Karkheh protected areas in Khuzestan Province are considered the only natural habitats for this mammal In Iran (Nabavi et al., 2010). This research has been conducted with the aim of determining the threat and pressure factors present in protected areas in Khuzestan Province and identifying protected areas in Khuzestan Province with the greatest threat and pressure factors. The scoring and prioritization of these factors have been carried out according to RAPPAM methodology.

\section{Study area}

Khuzestan Province with an area of $63633.6 \mathrm{~km}^{2}$ is situated between $29^{\circ} 57^{\prime}$ up to $33^{\circ} 0^{\prime}$ of the northern latitude off the equator and $47^{\circ} 40^{\prime}$ up to $50^{\circ} 33^{\prime}$ of the Eastern longitude of the Greenwich Median in the South West of Iran. Khuzestan Province has 19 areas under management with an area of 733102 hectares (Gitashenasi, 2007). among the most important protected areas in this province are Dez, Karkheh, Shalo and Mongasht, Shimbar, Koraii, and Haft Shahidan protected areas. The geographical location, area and characteristics of these studied protected areas are provided in Table 1 and Figure 1. 
Table1. The geographical location and area and characteristics of studied protected area

\begin{tabular}{|c|c|c|c|c|c|}
\hline $\begin{array}{l}\text { Protected } \\
\text { area }\end{array}$ & $\begin{array}{l}\text { North } \\
\text { latitude }\end{array}$ & $\begin{array}{c}\text { East } \\
\text { longitude }\end{array}$ & $\begin{array}{c}\text { Area } \\
\text { (ha) }\end{array}$ & Indicator fauna & Indicator flora \\
\hline Dez & $\begin{array}{l}32^{\circ} 15^{\prime}- \\
35^{\circ} 31^{\prime}\end{array}$ & $\begin{array}{l}48^{\circ} 21^{\prime}- \\
48^{\circ} 51^{\prime}\end{array}$ & 18711 & $\begin{array}{c}\text { Dama dama } \\
\text { mesopotamica, Vulpes } \\
\text { vulpes, Francoljnus } \\
\text { francdinus,Turdoides } \\
\text { altirostris }\end{array}$ & $\begin{array}{l}\text { Vitex seudonegando, } \\
\text { Capparis spinosa, } \\
\text { Calotropis frocera, } \\
\text { Rubus anatolica, } \\
\text { Populus euphratica }\end{array}$ \\
\hline Karkhe & $\begin{array}{l}32^{\circ} 57^{\prime}- \\
36^{\circ} 31^{\prime}\end{array}$ & $\begin{array}{l}48^{\circ} 10^{\prime}- \\
48^{\circ} 32^{\prime}\end{array}$ & 8600 & $\begin{array}{c}\text { Dama dama } \\
\text { mesopotamica, } \\
\text { Mellivora capensis, } \\
\text { Felis chaus, Canis } \\
\text { lupus, Marmaronetta } \\
\text { anas angustirostris, } \\
\text { Threskiornitis } \\
\text { aethiopicus, Ardeola } \\
\text { ralloides, Circus } \\
\text { macrourus }\end{array}$ & $\begin{array}{l}\text { Lycium depressurm, } \\
\text { Salix sp, Capparis } \\
\text { spinosa, Calotropis } \\
\text { frocera, Tamarix sp, } \\
\text { Cynodon dactylon, } \\
\text { Trifolium repens, Vitex } \\
\text { seudonegando }\end{array}$ \\
\hline Shimbar & $\begin{array}{c}32^{\circ} 39^{\prime}- \\
32^{\circ} 9^{\prime}\end{array}$ & $\begin{array}{c}49^{\circ} 30^{\prime}- \\
49^{\circ} 44^{\prime}\end{array}$ & 54139 & $\begin{array}{c}\text { Sciurus anomalus, } \\
\text { Martes foina, Canis } \\
\text { lupus, Herpestes } \\
\text { edwardsii, Ursus arctos, } \\
\text { Panthera pardus } \\
\text { saxicolor, Capra } \\
\text { aegagrus, Ovis } \\
\text { orientalis, Merops } \\
\text { aplaster, Alectoris } \\
\text { chukar, Ammoperdix } \\
\text { griseogularis }\end{array}$ & $\begin{array}{c}\text { Vitex pseudo, Populus } \\
\text { euphratica, marus alba, } \\
\text { Ficus carica, Quercus } \\
\text { branti, Amygdalus } \\
\text { scoparia, Mespilus } \\
\text { azarolus, Pistacia } \\
\text { atlantica, Pistacia } \\
\text { khinjuk, Myrtus } \\
\text { communis }\end{array}$ \\
\hline $\begin{array}{l}\text { Shalo and } \\
\text { Mongasht }\end{array}$ & $\begin{array}{l}31^{\circ} 35^{\prime}- \\
31^{\circ} 45^{\prime}\end{array}$ & $\begin{array}{l}50^{\circ} 15^{\prime}- \\
50^{\circ} 40^{\prime}\end{array}$ & 12992 & $\begin{array}{c}\text { Canis lupas, Ursus } \\
\text { arctos, Vulpes vulpes, } \\
\text { Alectoris chukar, } \\
\text { Ammoperdix } \\
\text { griseogularis, Canis } \\
\text { aureus }\end{array}$ & $\begin{array}{c}\text { Quercus brantii, Pistacia } \\
\text { khinjuk, Ficus carica } \\
\text { L.subsp rupestris, } \\
\text { Astragalus gummifer, } \\
\text { Crataegus aronia, } \\
\text { Amygdalus scoparia }\end{array}$ \\
\hline $\begin{array}{c}\text { Haft } \\
\text { Shahidan }\end{array}$ & $\begin{array}{c}32^{\circ} 3^{\prime}- \\
32^{\circ} 8^{\prime}\end{array}$ & $\begin{array}{c}49^{\circ} 04^{\prime}- \\
49^{\circ} 13^{\prime}\end{array}$ & 9609 & $\begin{array}{c}\text { Canis aureus, Canis } \\
\text { lupus, Vulpes vulpes, } \\
\text { Perdicinae sp, } \\
\text { Ammoperdix } \\
\text { griseogularis, } \\
\text { Streptopelia decaocto }\end{array}$ & $\begin{array}{l}\text { Zizyphus mauritiana, } \\
\text { Ziziphus nummularia, } \\
\text { Pistacia khinjuk, Ficus } \\
\text { carica L.subsp rupestris }\end{array}$ \\
\hline Koraii & $\begin{array}{l}31^{\circ} 35^{\prime}- \\
31^{\circ} 59^{\prime}\end{array}$ & $\begin{array}{l}49^{\circ} 00^{\prime}- \\
49^{\circ} 23^{\prime}\end{array}$ & 39420 & $\begin{array}{l}\text { Ovis orientalis, Canis } \\
\text { lupus, Canis aureus, } \\
\text { Cricetulus migratorius, } \\
\text { Felis silvestris, Hystrix } \\
\text { indica, Pipistrellus } \\
\text { pipistrellus, Martes } \\
\text { foina, Hyaena hyaena, } \\
\text { Lepus capensis, Egretta } \\
\text { garzetta, Upupa epops }\end{array}$ & $\begin{array}{c}\text { Zizyphus mauritiana, } \\
\text { Amyg dalus scoparia, } \\
\text { Achillea wilhelmsii, } \\
\text { Ficus carica, Pistacia } \\
\text { khinjuk }\end{array}$ \\
\hline
\end{tabular}

(Albodovirej, 1994; Dinarvand, 2015; Booklet annual report on protected areas in Khuzestan Province, 2015) 


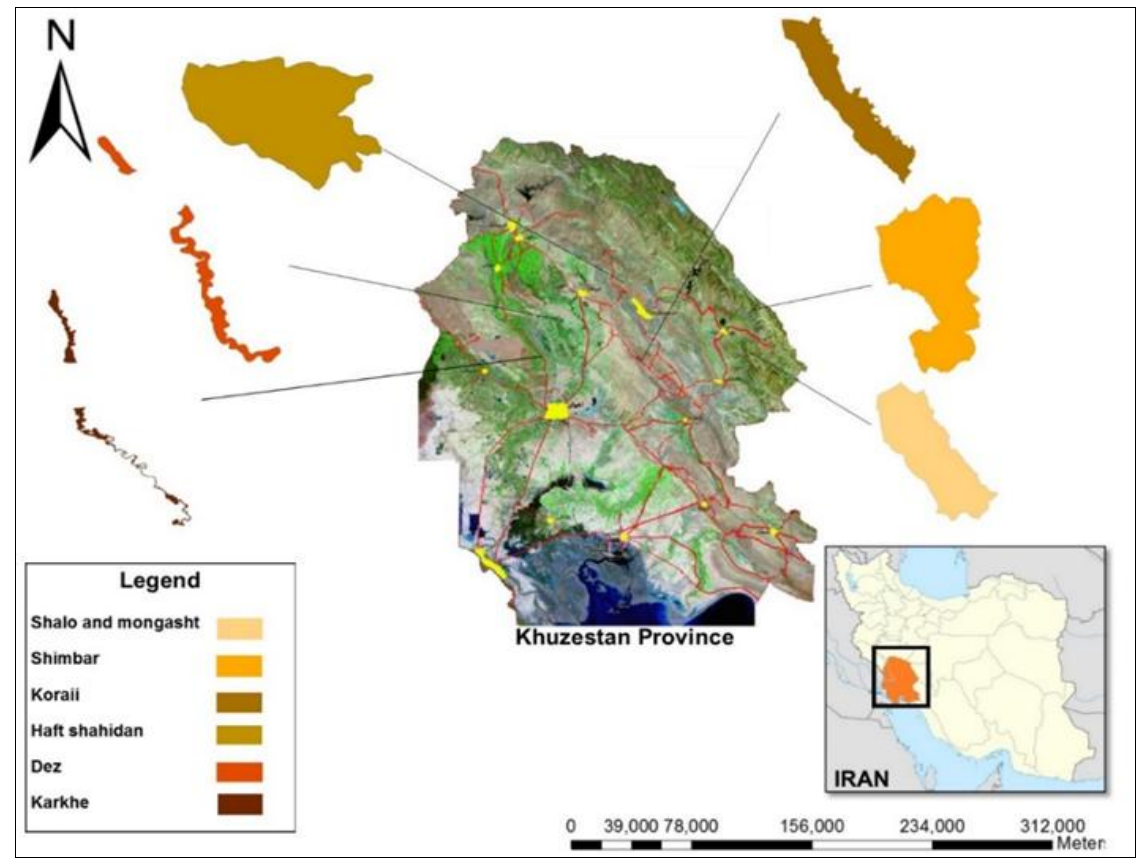

Figure 1. Situation of protected areas under study in Khuzestan Province

\section{Methodology}

In this research, RAPPAM methodology presented by WWF organization for rapid evaluation and protection prioritization of protected areas has been used (WWF, 2003). RAPPAM methodology has been prepared according to questionnaire method, where in this study after determining the study scope according to studies, reports, and valid evidence available on protected areas, a list of pressure and threat factors of the areas was prepared, where the factors and activities with greater effectiveness were chosen according to Delphi method. Delphi is a method based on intuitive opinions of experts in which a group of experts reach a consensus after expressing their opinions about a certain problem (Lang, 1994).

One of the reasons of choosing Delphi method is the most prominent feature of this method regarding its ability in integration of opinions among a diverse group of participants (Stitt-Gohdes et al., 2004).

Thereafter, according to RAPPAM methodology, the extent, impact, and permanence of the effects were scored by workgroups consisting of specialists and experts, managers, beneficiaries, and all stakeholders associated with studied protected areas. The extent of the effect is a range of pressure and threat factors on the region. The impact refers to the direct or indirect degree of threat and pressure on the resources of the protected area. Permanence of effect means the duration required for the resources affected by the protected area to be improved through human intervention or without it. "Improvement" denotes recovery of functions, ecological processes and structures before the occurrence of pressure or development of threat. The improvement time is referred to the duration required for mitigation or elimination of threat and pressure factors through managerial interventions or natural processes. Each of the mentioned characteristics was scored according to Table 2. 
Based on scoring in Table 2, the degree of pressure and threats is obtained through multiplication of three parameters, which can culminate in a score between 1 and 64 for each threat and pressure factor (WWF, 2003).

Table2. Description and Scoring For Threats and Pressures

\begin{tabular}{|c|c|c|c|}
\hline $\begin{array}{l}\text { Features } \\
\text { threat and } \\
\text { pressure }\end{array}$ & $\begin{array}{c}\text { The range of } \\
\text { threats and } \\
\text { pressure }\end{array}$ & Score & Description \\
\hline \multirow{4}{*}{ Extent } & Throughout & 4 & Activity occurs in 50 per cent or greater of its potential range \\
\hline & Widespread & 3 & Means occurrence in between 15 and 50 per cent \\
\hline & Scattered & 2 & Occurs in between 5 and 15 per cent \\
\hline & Localized & 1 & Occurs less than 5 per cent of its potential range \\
\hline \multirow{4}{*}{ Impact } & Severe & 4 & Impact is serious damage or loss to protected area resources \\
\hline & High & 3 & Impact is significant damage to protected area resources \\
\hline & Moderate & 2 & $\begin{array}{l}\text { Impact is damage to protected area resources that is } \\
\text { obviously detectable, but not considered significant }\end{array}$ \\
\hline & Mild & 1 & $\begin{array}{l}\text { Impact is damage that may or may not be easily detectable, } \\
\text { and is considered slight or insignificant }\end{array}$ \\
\hline \multirow{4}{*}{ Permanence } & Permanent & 4 & $\begin{array}{c}\text { Damage is damage to a resource that cannot recover, either } \\
\text { by natural processes or with human intervention, within } 100 \\
\text { years }\end{array}$ \\
\hline & Long term & 3 & Damage can recover in 20 to 100 years \\
\hline & Medium term & 2 & Damage can recover in 5 to 20 years \\
\hline & Short term & 1 & Damage can recover in less than 5 years \\
\hline
\end{tabular}

(WWF, 2003)

\section{Results and Discussion}

In this research, according to Delphi method, 20 questionnaires were given to the determined workgroups in order to specify the threat and pressure factors in the studied protected areas. The number of threat and pressure factors in the protected areas obtained based on Delphi method included 14 factors in Dez protected area, 14 factors in Karkhe protected area, 14 factors in Shimbar protected area, 13 factors in Shalo and Mongasht protected area, 15 factors in Haft Shahidan protected area, and 12 factors in Koraii protected area, provided in Table 3. Thereafter, according to RAPPAM methodology, scoring was conducted and the results obtained from scoring of the threat and pressure factors in the studied protected areas are provided in Diagrams (Figure 2 and Figure 3). 
Table 3. List of Pressures and Threats used in the Evaluation of Protected Areas in Khuzestan Province, Iran

\begin{tabular}{|c|c|c|c|c|c|c|c|c|}
\hline $\begin{array}{l}\text { Threat and pressure } \\
\text { factors }\end{array}$ & 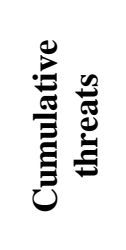 & 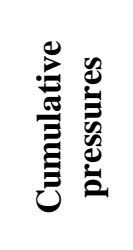 & $\stackrel{๊}{\mathscr{0}}$ & 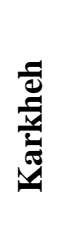 & 离 & 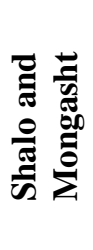 & 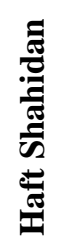 & 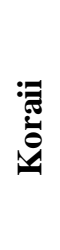 \\
\hline Drought & 133.44 & 143.19 & & & & $\checkmark$ & $\checkmark$ & $\checkmark$ \\
\hline Fire & 56.7 & 56.87 & $\checkmark$ & $\checkmark$ & $\checkmark$ & $\checkmark$ & $\checkmark$ & $\checkmark$ \\
\hline Overgrazing & 205.98 & 201.07 & $\checkmark$ & $\checkmark$ & $\checkmark$ & $\checkmark$ & $\checkmark$ & $\checkmark$ \\
\hline Cutting tree & 113.43 & 130.29 & $\checkmark$ & $\checkmark$ & $\checkmark$ & $\checkmark$ & $\checkmark$ & $\checkmark$ \\
\hline Conversion of land use & 137.77 & 145.46 & $\checkmark$ & $\checkmark$ & $\checkmark$ & $\checkmark$ & $\checkmark$ & $\checkmark$ \\
\hline Shortage of workforce and equipment & 152.96 & 185.26 & $\checkmark$ & $\checkmark$ & $\checkmark$ & $\checkmark$ & $\checkmark$ & $\checkmark$ \\
\hline Hunting & 101.17 & 104.77 & $\checkmark$ & $\checkmark$ & $\checkmark$ & $\checkmark$ & $\checkmark$ & $\checkmark$ \\
\hline Turism effectiveness & 65.97 & 60.61 & $\checkmark$ & $\checkmark$ & $\checkmark$ & $\checkmark$ & $\checkmark$ & $\checkmark$ \\
\hline $\begin{array}{l}\text { Not having a clear boundary with } \\
\text { adjacent land }\end{array}$ & 95.28 & 77.9 & $\checkmark$ & $\checkmark$ & $\checkmark$ & $\checkmark$ & $\checkmark$ & $\checkmark$ \\
\hline Air pollution by natural and unnatural & 73.81 & 68.92 & $\checkmark$ & $\checkmark$ & $\checkmark$ & $\checkmark$ & $\checkmark$ & $\checkmark$ \\
\hline Dam building & 197.79 & 176.46 & $\checkmark$ & $\checkmark$ & $\checkmark$ & $\checkmark$ & $\checkmark$ & $\checkmark$ \\
\hline Flora pests & 78.61 & 72.03 & $\checkmark$ & $\checkmark$ & $\checkmark$ & $\checkmark$ & $\checkmark$ & $\checkmark$ \\
\hline Fauna pests & 29.49 & 32.1 & $\checkmark$ & $\checkmark$ & & & & \\
\hline $\begin{array}{l}\text { River pollution and the forest } \\
\text { effectiveness }\end{array}$ & 42.94 & 34.8 & $\checkmark$ & $\checkmark$ & & & & \\
\hline $\begin{array}{l}\text { The effects caused by immigration of } \\
\text { nomads }\end{array}$ & 24.5 & 20.33 & & & $\checkmark$ & & & \\
\hline Industrial- Seismography projects & 25.28 & 25.85 & & & & & $\checkmark$ & \\
\hline Oil exploration and operation & 32.57 & 37.71 & & & & & $\checkmark$ & \\
\hline Establish the Roads & 91.49 & 88.44 & & & $\checkmark$ & $\checkmark$ & $\checkmark$ & \\
\hline
\end{tabular}

Protected areas are among the most important instruments for protecting the biodiversity and services of ecosystems (Scharlemann et al., 2010; Klein et al., 2007; Coad et al., 2008) and are the basis of forest protector policies in developing countries (Assessment, 2005). This has resulted in development of protected areas of over $15.4 \%$ of the earth surface in every land section (Juffe-Bignoli et al., 2014). In spite of this extensive coverage, biodiversity is still declining (Butchart et al., 2010; Tittensor et al., 2014), since protection from areas is only one aspect of the performance and effectiveness of the protected areas. In other words, areas require a legal framework and suitable administrative structure to aid in halting loss of biodiversity (Leverington et al., 2010; Watson, 2014). 


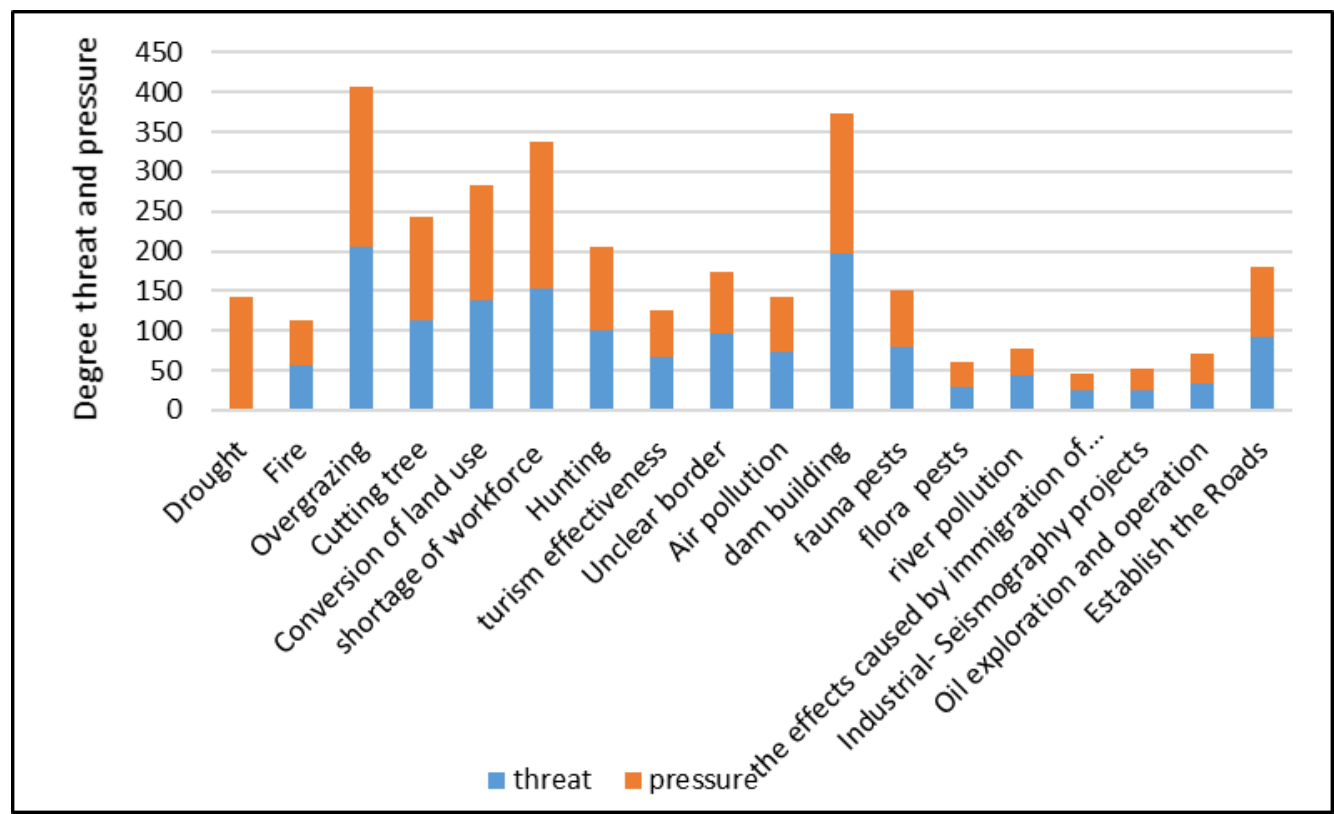

Figure 2. Cumulative degree of pressures and threats of protected areas under study in Khuzestan Province,Iran

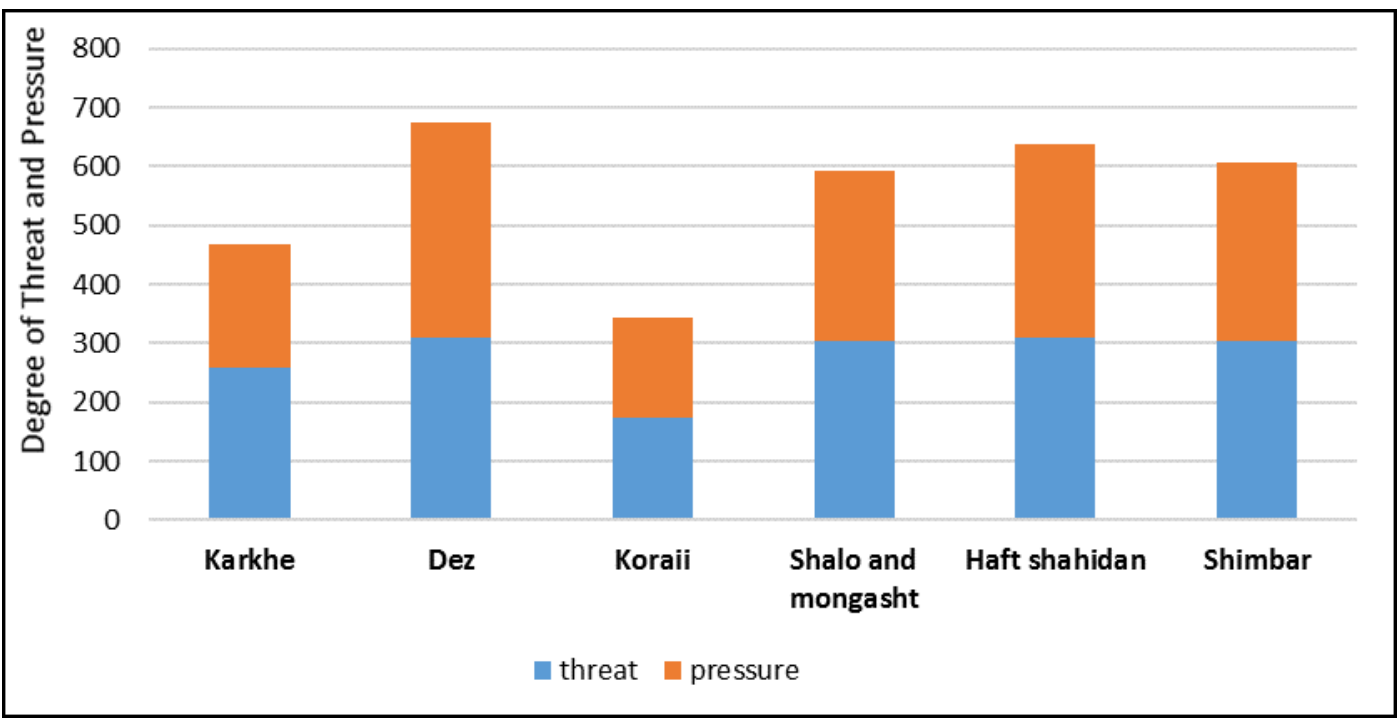

Figure 3. Cumulative degree of pressures and threats of protected areas under study in Khuzestan Province.Iran

Protective measures need the support of local communities and if a national park does not receive political and financial support from the central government, application of protective measures that realizes the goals of the local community becomes difficult (Hadjibiros and Sifakak, 2009). Due to this reason, decreased biodiversity is still taking place inside the boundaries of protected areas (Butchart et al., 2010; Tittensor et al., 2014) and the current level of management of protected areas to "stop loss of biodiversity" in a global scale is not adequate (Watson et al., 2014). 
The results of this study suggest that five major collective threat and pressure factors across all protected areas in Khuzestan Province are overgrazing (405.07), dam building (374.25), shortage of workforce and equipment (338.22), conversion of land use (283.23), and cutting of trees (243.72).

According to studies conducted in Nepal (Nepali, 2006), Butane (Tshering, 2003), Georgia (Zazanashvili, 2003), and National parks (Nchor et al., 2012), overgrazing has the greatest impact and is the major threat and pressure factor in protected areas. Mountainous rangelands and Meadows are intensely affected by overgrazing, such that overgrazing diminishes food production for the wildlife and causes desertification (Li et al., 2003). Similarly, in some regions due to sensitivity of areas and lack of sufficient time for improvement, overgrazing is increasing with a greater intensity. In many areas, due to high altitude, agriculture is not possible and thus the life of local communities is dependent on grazing (Tshering, 2003). However, grazing in high altitude areas not only involves grazing but also local communities of wild animals, especially during night when night-active species are active (Nepali, 2006). Nevertheless it is clear that the impact, scale, and extent of grazing are different from park to park (Tshering, 2003). Grazing can cause natural disorders in the soil chemical processes, while simultaneously causing soil erosion. However, overgrazing, if not properly managed, often results in problems. In general, by introducing disorders into the physical characteristics and population of species, grazing affects the ecosystem. Not covering the land causes susceptibility of erosion and increased production of weeds. Vegetation helps soil in prevention from erosion and runoff during rainfall. However, when grazing takes place, the plant structure of the society changes and thus the society or biomass is destroyed (Azarnivand et al., 2011). Nevertheless, it should be noted that grazing can be benefited from as a good managerial method for preserving biodiversity and frequency in the long-term in enclosed rangelands (Wu et al., 2009).

Dam building claimed the second position among the major threat and pressure factors. Considering the long drought and effect of human, natural resources are atrisk. This has resulted in caring for the significance of the quantity and quality of water resources for proper management and exploitation of water resources in terms of sustainable development (Mouratidis et al., 2010). Until 2014, about 37641 have been constructed in the world (ICOLD, 2014). Many of the environmental impacts of dams are immediate and evident. However, other environmental effects are gradual and latent and can be hardly predicted (Johnson, 1998). These effects often develop across the entire river basin including changes in sedimentation and water flow as well as losing aquatic animals and losing or developing disorders in forests, flood plains, and other ecosystems (Fearnside, 2016). Therefore, when planning and managing water resources, the significance of adaptation of the executed plan with meteorological changes has been underscored (Khoi and Thom, 2015).

Shortage of workforce and equipment has been identified as the third threat and pressure factor for protected areas in Khuzestan Province. Overall, human and financial resources, planning, and efficient environmental management are required for proper management of protected areas (de Almeida et al., 2016). Shortage of area staff especially trained staff and the low motivation of employees as the major constraints affect the private forestry plan in Nepal (Chaudhary, 2000).

In addition to protected areas in Khuzestan Province, conversion of land use has been identified as the major factor of forest destruction and deforestation in 
Romania (Stanciu and Steindlegger, 2006) and Philippine (Verburg et al., 2006). Protected areas have been established for limiting the extent of changes in land use in areas with biodiversity and are large areas for conservation of at-risk species. Land-use and Land Coverage Changes (Lucc) can be a major threat for biodiversity, destruction of natural vegetation, segmentation or separation of areas in the nature (Bates and Rudel, 2000). Studies have shown that exploitation of lands and changing their use cause altered biodiversity (Shackleton, 2000). In management of these areas, altered land-use across the entire protected areas is very different, but nearly the development of agricultural activities and growth of residential communities in protected areas can be observed around the world (Bailey, 2015). If this elevation of agricultural lands in the proximity of protected areas is not properly managed, the resources of protected areas would be most probably adversely affected (Davis and Hansen, 2011).

The fifth threat and pressure factor is cutting of trees, accounting for $50 \%$ of the threat of areas in Cambodia (Lacerda et al., 2004). According to studies conducted in this research, the lowest collective threat and pressure factor is related to the effects caused by integration of nomads. This factor is natural according to expectations of experts, since the nomads residing in the nature have gradually adapted to the environment and prevented its destruction. This is because if these areas are destructive, their life would break down in return. In protected areas studied in Khuzestan Province, the greatest collective pressure and threat factor is related to Dez protected area (674.41), whereas the lowest pressure and threat factor is related to Koraii protected area (342.51). This can suggest unsuitability of conditions and facilities as the origin of threat and pressure factors in Dez protected area and to some extent appropriateness of these conditions and facilities in Koraii protected area in comparison with other areas.

\section{Conclusion}

This research states that overgrazing, dam construction, shortage of workforce and equipment, altered land-use, and cutting of trees are among the most important threat and pressure factors in protected areas in Khuzestan Province. It is essential that management of the areas introduce special solutions for eliminating or at least minimizing these pressure and threat factors regarding the objectives of the area. With elimination or mitigation of the effects of these pressure and threat factors, they can prevent destruction of areas. These solutions can be presented in short-term planning for removing or mitigating the pressure factors and long-term plans for eliminating threats factors of the areas in the future. Among these solutions can one mention offering the license of grazing to local communities in the area in a periodical fashion and supervising uniform distribution of grazing in this period, consideration of incentive measures for the area's staff in order to enhance motivation and aid in conservation of the area, holding training courses for the staff suited with the new needs of the area including the courses related to pests and animal diseases in the area, recovery of the boundaries of the protected areas to prevent to transgression to the area and alteration of land use, zoning of the areas and developing zone buffer, and constant monitoring of the area as well as the vegetation using remote sensing data, training of local communities residing in the areas considering the significance and functions of the protected area. 


\section{REFERENCES}

[1] Albodovirej, H. (1994): Information Dez Protected Area. - Department of Environment Islamic Republic of Iran, Khuzestan Provincial Office.

[2] Assessment, M. E. (2005): Millennium ecosystem assessment. Ecosystems and human wellbeing: a framework for assessment. - Washington D.C.: Island Press.

[3] Azarnivand, H., Farajollahi, A., Bandak, E., Pouzesh, H. (2011): Assessment of the Effects of Overgrazing on the Soil Physical Characteristic and Vegetation Cover Changes in Rangelands of Hosainabad in Kurdistan Province, Iran. - Journal of Rangeland Science 1(2): 95-102.

[4] Bailey, K. M., McCleery, R. A., Binford, M. W., Zweig, C. (2015): Land-cover change within and around protected areas in a biodiversity hotspot. - Journal of Land Use Science 11(2): 154-176.

[5] Bates, D., Rudel, T. K. (2000): The political ecology of conserving tropical rain forests: A cross-national analysis. - Society \& Natural Resources 13(7): 619-634

[6] Batsukh, N., Belokurov, A. (2005): Mongolia: Management Effectiveness Assessment of the Mongolian Protected Areas, System using WWF's RAPPAM Methodology. - WWFMongolia: 46.

[7] Booklet annual report on protected areas in Khuzestan province. (2015): Department of Environment Islamic Republic of Iran, Khuzestan Provincial Office.

[8] Butchart, S. H. M., Walpole, M., Collen, B., Van Strien, A., Scharlemann, J. P., Almond, R. E., Baillie, J. E., Bomhard, B., Brown, C., Bruno, J., Carpenter, K. E. (2010): Global biodiversity: indicators of recent declines. - Science 328: 1164-1168.

[9] Chaudhary, R. M. (2000): Forest conservation and environmental management in Nepal: a review. - Biodiversity and Conservation 9: 1235-1260.

[10] Coad, L., Burgess, N., Fish, L., Ravilious, C., Corrigan, C., Pavese, H., Granziera, A., Besancon, C. (2008): Progress Towards the Convention on Biological Diversity Terrestrial 2010 and Marine 2012 Targets for Protected Area Coverage. - Nature Bureau, UK, Gland, Switzerland.

[11] Davis, C. R., Hansen, A. J. (2011): Trajectories in land use change around U.S. National Parks and challenges and opportunities for management - Ecological Applications 21(8): 3299-3316.

[12] de Almeida, L. T., Olímpio J. L. S, Pantalena A. F., de Almeida, B. S., de Oliveira Soares, M. (2016): Evaluating ten years of management effectiveness in a mangrove protected area. - Ocean \& Coastal Management 125: 29-37.

[13] Dinarvand, M., Ejtehadi, H., Jankju, M., Andarziyan, B. (2015): Study of floristics, life form and chorology of plants in Shimbar protected area (Khuzestan province), Iranian. Journal of Plant Biology 7(23): 1-14.

[14] Fearnside, Ph. M. (2016): Environmental and Social Impacts of Hydroelectric Dams in Brazilian Amazonia: Implications for the Aluminum Industry. - World Development 77: 48-65.

[15] Gitashenasi. (2007): Road Atlas of Iran, Gitashenasi Geographic and Cartographic Institute, First Edition. - Tehran, Iran. 304.

[16] Giuliani, A. (2007): Assessing the Human Impact of Protected Areas. - IIED and UNEP WCMC: 97.

[17] Goodman, P. S. (2003): South Africa: Management Effectiveness Assessment of Protected Areas in KwaZulu-Natal using WWF's RAPPAM Methodology. - WWF, Gland, Switzerland: 33.

[18] Hadjibiros, K. Sifakaki, P. (2009): Schinias Wetland: A National Park OR A Solar Saltwork? - Global NEST Journal 11(1): 32-40.

[19] Hockings, M., Sue S., Fiona, L., Nigel, D., José, C., Peter, V. (2010): Evaluating Effectiveness A framework for assessing management effectiveness of protected areas 2nd Edition. - IUCN, Rue Mauverney 28, 1196 Gland, Switzerland: 121. 
[20] ICOLD (International Commission on Large Dams). (2014): World Register of Dams, General Synthesis.

[21] Johnson, W. C. (1998): Adjustment of riparian vegetation to river regulation in the great plains, USA. - Wetlands 18(4): 608-618.

[22] Juffe-Bignoli, D., Burgess, N. D., Bingham, H., Belle, E. M. S., De Lima, M. G., Deguignet, M., Bertzky, B., Milam, A. N., Martinez-Lopez, J., Lewis, E., Eassom, A. (2014): Protected Planet Report 2014. - United Nations Environment Program World Conservation Monitoring Centre (UNEP-WCMC), Cambridge, UK.

[23] Khoi, D. N., Thom, V. T. (2015): Impacts Climate Variability and Land-use Change On Hydrology In The Period 1981-2009 in the Central Highlands of Vietnam. - Global NEST Journal 17(4):870-881.

[24] Klein, A. M., Vaissiere B. E., Cane J. H. Steffan-Dewenter, I., Cunningham, S. A., Kremen, C., Tscharntke, T. (2007): Importance of pollinators in changing landscapes for world crops. - Proc. R. Soc. B Biol. Sci 274: 303-313.

[25] Lacerda, L., Schmitt, K., Cutter, P., Meas, S. (2004): Management Effectiveness Assessment of the System of Protected Areas in Cambodia using WWF's RAPPAM Methodology. - Ministry of Environment, Biodiversity and Protected Areas Management Project, Phnom Penh, Cambodia: 30.

[26] Lang, T. (1994): An overview of four futures methodologies. - Retrieved: December 1, 2005.

[27] Leverington, F., Costa, L. K., Pavese, H., Lisle, A., Hockings, M. (2010): A global analysis of protected area management effectiveness. - Environmental Management 46(6): 685-698.

[28] Leverington, F., Hockings, M., Pavese, H., Costa, L. K., Courrau, J. (2008): Management Effectiveness Evaluation in Protected Areasda Global Study. Supplementary Report No. 1: Overview of Approaches and Methodologies. - The University of Queensland, Gatton, TNC, WWF, IUCN-WCPA, Gatton, Australia: 188.

[29] Li, D., Zhou, J., Dong, K., Wu, B., Zhu, C. (2003): China Management Effectiveness Assessment of Protected Areas in the Upper Yangtze Ecoregion using WWF's RAPPAM Methodology. - WWF, Gland, Switzerland: 28.

[30] Mansoori, J. (2008): A field guide to the birds of Iran (second edition). - Farzaneh Publishing, Tehran: 513.

[31] Mirkarimi, S. H. (2007): Landscape ecological planning for protected areas using spatial and temporal metrics. - PhD thesis, Land Information, RMIT University, Melbourne, Victoria.

[32] Mouratidis, I., Dimopoulos, G., Astaras, T., Savvidis, S. (2010): Sustainable Water Resources Management Through The Use Of GIS Technologies. - Global NEST Journal 12(2): 140-151.

[33] Nabavi, S. M. B., Behrouzi Rad, B. Padash, A. (2010): Atlas of Birds and Mammals Distribution in Khuzestan Provincial (First Edition). - Department of Environment Islamic Republic of Iran, Khuzestan Provincial Office Publishing: 460.

[34] Nchor, A. A., Ogogo, A. U. (2012): Rapid Assessment of Protected area Pressures and Threats in Nigeria National Parks. - Global Journal of Agricultural Sciences 11(2): 6372.

[35] Nepali, S. C. (2006): Nepal Management Effectiveness Assessment of Protected Areas using WWF's RAPPAM Methodology. - Published by WWF Nepal Program: 36.

[36] Nolte, C., Leverington, F., Kettner, A., Marr, M., Nielsen, G., Bomhard, B., Stolton, S., Stoll-Kleemann, S., Hockings, M. (2010): Protected area management effectiveness assessments in Europe. A review of applications, methods and results. - BfN-Skripten 271a, Bonn.

[37] Rana, M. P., Sohel, M. S. I., Mukul, S. A., Chowdhury, M. S. H., Akhter, S., Koike, M. (2010): Implications of ecotourism development in protected areas: a study from Rema Kalenga Wildlife Sanctuary, Bangladesh - iForest(3) : 23-29 
[38] Sabzghabaei, G. R., Monavari, S. M., Riazi, B., Khorasani, N., Karami, M. (2015): Analysing pressures and threats on the Southern Wetlands of Iran with the application of RAPPAM methodology (Case study: Khuzestan Province). - Global NEST Journal 17(2): 344-356.

[39] Scharlemann, J. P. W., Kapos, V., Campbell, A. Lysenko, I., Burgess, N.D., Hansen, M. C., Gibbs, H. K., Dickson, B., Miles, L. (2010): Securing tropical forest carbon: the contribution of protected areas to REDD. - Oryx 44: 352-357.

[40] Secretariat of the Convention on Biological Diversity. (2008): Protected Areas in Today's World: Their Values and Benefits for the Welfare of the Planet. - Technical Series (36).

[41] Shackleton, C. M. (2000): Comparison of plant diversity in protected and communal lands in the Bushbuckridge lowveld savanna, South Africa. - Biological Conservation (94): 273-285.

[42] Simões, L. L., Oliveira, L. R., Mattoso, A., Pisciotta, K., Silva Noffs, M. D., Raimundo, S., Leite, S., Naumann, M., Onaga, S. (2010): Implementation of the Rapid Assessment and Prioritization of Protected Area Management by the Forestry Institute and the Forestry Foundation of São Paulo. - Gland, Switzerland: 44.

[43] Stanciu, E., Steindlegger, G. (2006): RAPPAM (Rapid Assessment and Prioritization o Protected Area Management) Methodology Implementation in Romania: Key findings and results. - WWF: 61.

[44] Stitt-Gohdes, W. L. S., Crews, T. B. (2004): The Delphi Technique: A Research Strategy For Career And Technical Education. - Career and Technical Education 20(2): 55-67.

[45] Tittensor, D. P. Walpole, M., Hill, S. L., Boyce, D. G., Britten, G. L., Burgess, N. D., Butchart, S. H., Leadley, P. W., Regan, E. C., Alkemade, R., Baumung, R. (2014): Amidtermanalysis of progress toward international biodiversity targets. - Science 346: 241244.

[46] Tshering, K. (2003): Bhutan Management Effectiveness Assessment of Four Protected Areas using WWF's RAPPAM Methodology. - WWF, Gland, Switzerland: 30.

[47] Tyrlyshkin, V., Blagovidov A., Belokurov, A. (2003): Russia Management Effectiveness Assessment of Protected Areas. - WWF's RAPPAM Methodology. Gland, Switzerland.

[48] Verburg, P. H., Overmars, K. P., Huigen, M. G., de Groot, W. T., Veldkamp, A. (2006): Analysis of the effects of land use change on protected areas in the Philippines. - Applied Geography 26:153-173.

[49] Watson, J. E. M., Dudley, N., Segan, D. B., Hockings, M. (2014): The performance and potential of protected areas. - Nature 515: 67-73.

[50] Wu, G. L., Du, G. L., Liu, Z. H., Thirgood, S. (2009): Effect of fencing and grazing on a Kobresia-dominated meadow in the Qinghai-Tibetan Plateau. - Plant Soil 319: 115-126.

[51] WWF. (2003): Rapied Assessment prioritization of Protected Area Management (RAPPAM) Methodology. - Gland, Switzerland: 36.

[52] Zazanashvili, N., Dzneladze, M. A., Belokurov, A. (2003): Georgia Management Effectiveness Assessment of Protected Areas using WWF's RAPPAM Methodology. WWF, Georgia.

[53] Zyaii, H. (2008): A field guide to the mammals of Iran. - Department of Environment Islamic Republic of Iran Publishing, Tehran: 419. 